Journal of Scientific Perspectives

Volume 3, Issue 3, Year 2019, pp. 237-244

E - ISSN: 2587-3008

URL: http://ratingacademy.com.tr/ojs/index.php/jsp

DOİ: https://doi.org/10.26900/jsp.3.025

Research Article

\title{
EFFECTS OF BLACKBERRY AND BLACKTHORN FRUIT EXTRACTS ON PROTEIN AND PEROXIDASE ACTIVITY IN PEPPER
}

\author{
Cahit YILDIZ * \& Cüneyt AKI ** \\ * MSc Student, Çanakkale Onsekiz Mart University, Graduate School of Natural and Applied \\ Sciences, TURKEY, e-mail: cahit.yildiz@outlook.com \\ ORCID ID: https://orcid.org/0000-0002-4132-0858 \\ ** Prof. Dr., Çanakkale Onsekiz Mart University, Faculty of Science and Arts, Department of Biology, \\ Subdivision of Molecular Biology, TURKEY, e-mail: cuneytaki@comu.edu.tr \\ ORCID ID: https://orcid.org/0000-0002-7486-2282
}

Received: 26 April 2018; Accepted: 28 June 2019

\begin{abstract}
In this research, blackthorn (Prunus spinosa L.) and blackberry (Rubus sanctus Schreb.) fruits have been extracted with water, ethanol, ethanol/water solvents. Fruit extracts were sprayed on the leaves of grossum and conoides varieties of Capsicum annuum L.. 24 and 48 hours after extract applications, healthy leaf of ten weeks old seedlings were harvested for protein and peroxidase analyses. Changing in total protein levels and peroxidase activity were measured spectrophotometrically. The highest total protein level increase was in the application of ethanolic extract of $R$. sanctus to grossum variety when we compare with control group. This increasing 24 and 48 hours after application were determined as $154 \%$ and $144 \%$ respectively. After the applications of $R$. sanctus fruit extract to the grossum and conoides varieties, peroxidase (POX) [EC 1.11.1.7] activity changing have been found better than P. spinosa extract application. After the both fruit extract applications, increasing in the $P O X$ activity of conoides variety have been found better than the grossum variety. 24 and 48 hours after application of ethanolic $R$. sanctus extract to conoides variety, POX activity increasing have been found respectively as $76 \%$ and $94 \%$. In conclusion, it was shown that $P$. spinosa and $R$. sanctus fruit extracts have been stimulated the plant defense system in grossum and conoides varieties of $C$. annuum at different levels within the scope of total protein amount and peroxidase activity according to the control group.
\end{abstract}

Keywords: Prunus spinosa, Rubus sanctus, Total protein, Peroxidase, Capsicum annuum. 


\section{INTRODUCTION}

Turkey has a rich natural biodiversity which has a great amount of medicinal and aromatic plant species. Nowadays, their usage aren't limited with medicine, food, bewerage, cosmetic industry and veterinary medicine. Organic farming and in phytoremedition as bioaccumulator are the potential usage fields of these plants (Bağdat, 2006). In addition, there are studies that use the extracts prepared from plants as a stimulant for plant defense. For example, the studies of Goupil et al. (2012), was shown that both leaf infiltration and a foliar spray of the red grape extract on tobacco leaves induced defence gene expression: The PR1 and PR2 target genes were upregulated locally and systemically in tobacco plants following grape marc extract treatment. The grape extract elicited an array of plant defence responses making this natural compound a potential phytosanitary product with a challenging issue. Kulaksiz (2016), determined that different concentrations and exposure time of Aloe vera gels has been stimulated the plant defense system in different ratios. In this study, it has been found that low concentration Aloe vera gel increases the peroxidase activity in grossum varieties of Capsicum annuum. In the study of Dinç and Akı (2015), shown that the application of ethanolic and methanolic extracts of Echinacea angustifolia to Solanum lycopersicon seedlings decreased the amount of total protein in the Solanum lycopersicum seedlings and increased peroxidase activity. It was determined these effects vary depending on the extraction concentration and time. In the study of Y1ldiz and Ak1 (2018), it was shown that Prunus spinosa and Rubus sanctus leaf raw extracts were able to stimulate plant defense system at different levels.

\section{MATERIAL AND METHODS}

\subsection{Material}

In this research, the $C$. апnиum seeds have been used as a plant material. Seeds were purchased from Küçük Çiftlik Company. Wild Blackberry (R. sanctus) fruits were collected from Terzioğlu Campus of Çanakkale Onsekiz Mart University. Blackthorn (P. spinosa) fruits were collected from Sarıcaeli Village of Çanakkale.

\subsection{Methods}

\subsubsection{Growing of Pepper Seedlings}

The seeds of Capsicum annuum varieties (conoides and grossum) were germinated in violes (capacity 45) containing a mixture of $1 / 3$ perlite-peat under controlled conditions. The seedlings were grown in controlled plant growth chamber at $24 \pm 2{ }^{\circ} \mathrm{C}$ and $60 \%$ humidity, under $16 / 8$ hours long day photoperiod. All of the trials were replicated three times. 10 weeks old seedlings have been used for the experiments.

\subsubsection{Prepearing of Fruit Extracts}

For the extraction process, fresh fruits of $R$. sanctus and P. spinosa, were used. The fruits were shredded with hand blender. Very small pieces of $P$. spinosa and $R$. sanctus fruits were weighed $25 \mathrm{~g}$ each and final volume of $50 \mathrm{~mL}$ of water, ethanol/water and ethanol solvents were prepared. The prepared solutions have been shake at $130 \mathrm{rpm}$ for 6 hours in the room temperature. Then all of the solvents were evaporated in the water bath at $60^{\circ} \mathrm{C}$ for 5 hours. The resulted powders of the fruit extracts were weighed $2 \mathrm{~g}$ each and stored at $-20^{\circ} \mathrm{C}$ until the application.

\subsubsection{Dissolution of Extracts with DMSO}

$2 \mathrm{~g}$ of fruit extracts were taken and stock solution was prepared with $20 \mathrm{~mL}$ of dimethyl sulfoxide (DMSO). The stock solution was diluted with distilled water and an application concentration of $10 \mathrm{mg} / \mathrm{mL}$ was prepared. 


\subsubsection{Application of the Fruit Extracts to $C$. annuum varieties}

The stock solutions were diluted with distilled water as $0.01 \mathrm{~g} / \mathrm{mL}(10 \mathrm{~mL}$ of stock $/ 90 \mathrm{~mL}$ of distilled water) for application. Diluted stock solutions were sprayed on leaves of 10-weekold "conoides" and "grossum" varieties of $C$. апnииm seedlings. Control groups were sprayed with distilled water.

\subsubsection{Analysis Procedure}

\subsubsection{Homogenization of Harvested Leaves}

After of the application 24 and 48 hours, the healthy leaves of pepper seedlings were harvested. These leaves were homogenized with $5 \mathrm{~mL} 0.05 \mathrm{M}$ cold sodium acetate buffer $(\mathrm{pH}$ : 6.5) for one minute. Then these homogenants were centrifuged $13000 \mathrm{rpm}$ at $+4^{\circ} \mathrm{C}$ for 15 minutes. After the centrifugation, the supernatant were used for determination of total protein analysis and peroxidase (POX) activity.

\subsubsection{Total Protein Level and Peroxidase Activity Analyses}

The total protein amount in the homogenates was determined by spectrophotometric analysis according to Bradford (1976)'s method using bovine serum albumin (BSA) as a standard. Peroxidase (POX) activity changes in homogenants were determined by spectrophotometric analysis according to the method of Kanner and Kinsella (1983).

\section{RESULTS AND DISCUSSION}

\subsection{Protein Results}

When compared with the control group, it was determined that all plant extracts of this research caused an increasing in the total amount of protein. The highest increase in the total protein amount have been found in both varieties of $C$. annuum ethanolic extract application of both fruits.

24 and 48 hours after application of ethanolic $P$. spinosa extract to grossum variety, total protein levels increasing have been found respectively as $134 \%$ and $127,5 \%$.

Fig. 1 Effects of P. spinosa Extracts on Total Protein Amount in C. annuum var. grossum

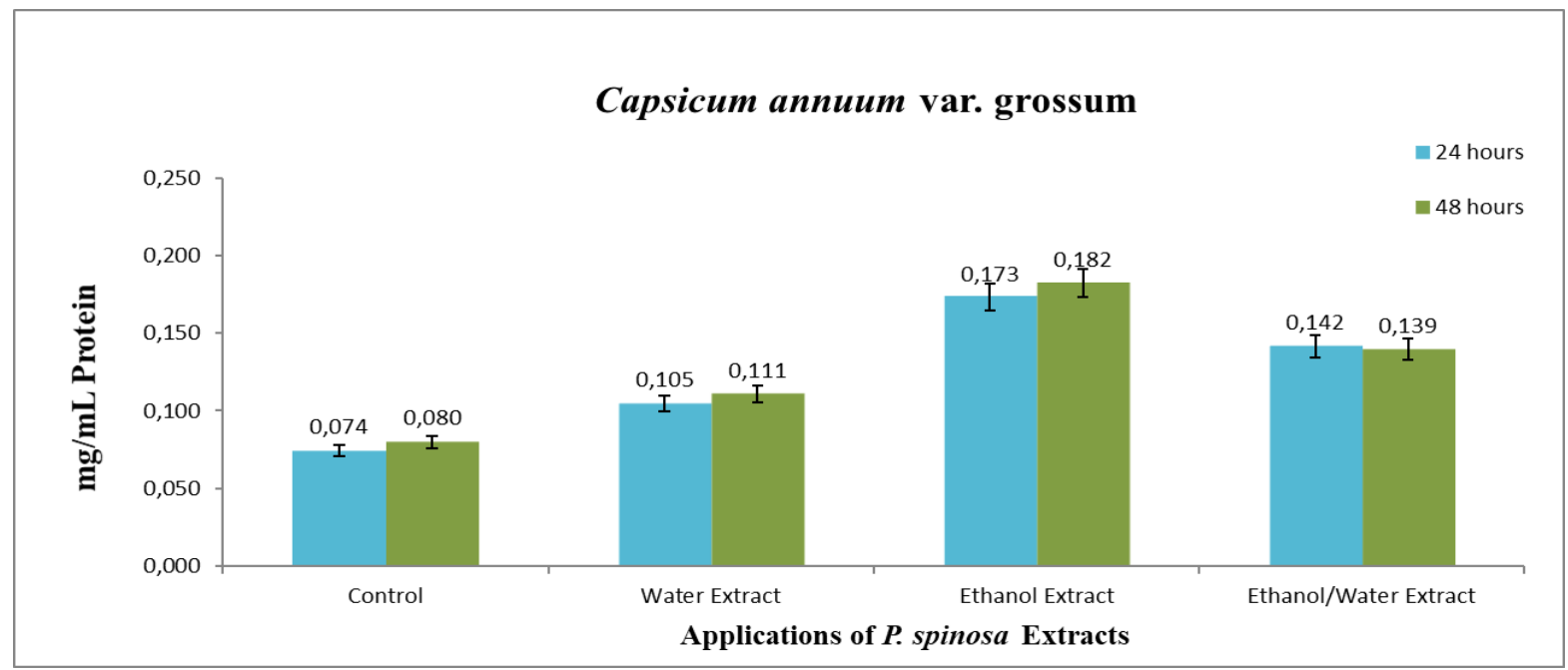

The highest total protein level increase was in the application of ethanolic extract of $R$. sanctus to grossum variety when we compare with control group. This increasing 24 and 48 hours after application were determined as $154 \%$ and $144 \%$ respectively. 
Fig. 2 Effects of $R$. sanctus Extracts on Total Protein Amount in C. annuum var. grossum

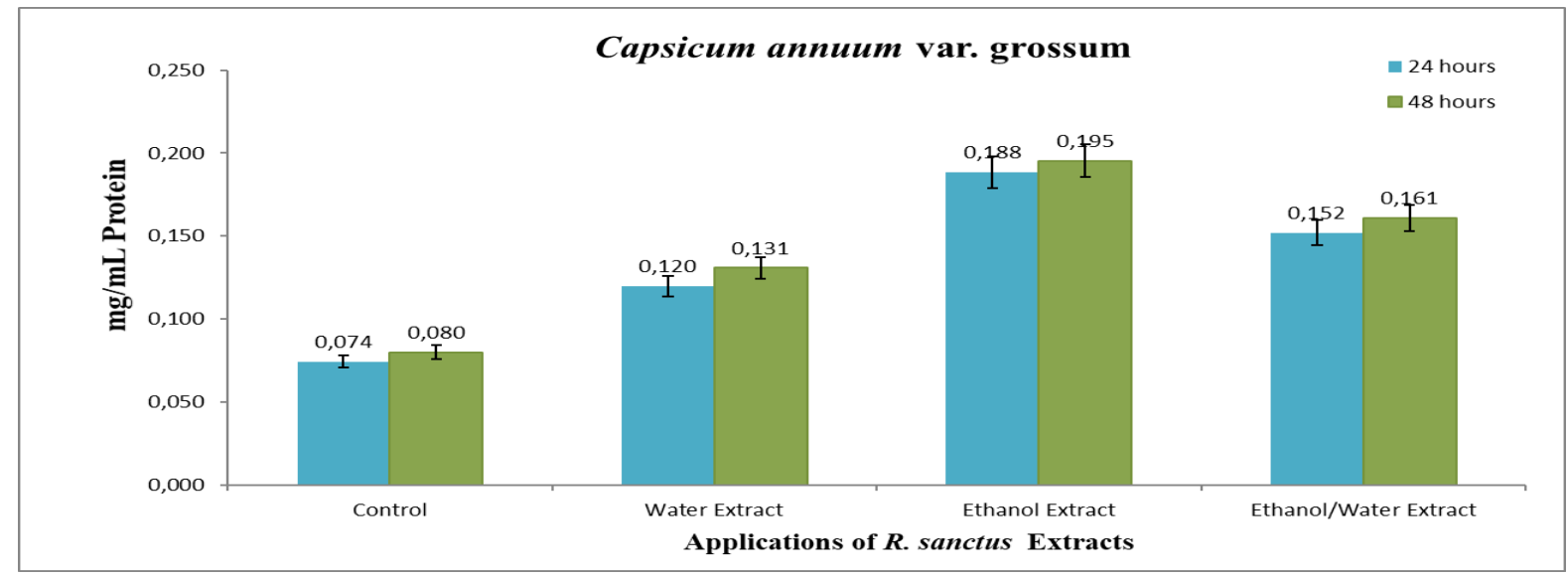

24 and 48 hours after application of ethanolic $P$. spinosa extract to conoides variety, total protein levels increasing have been found respectively as $138 \%$ and $121 \%$.

Fig. 3 Effects of $P$. spinosa Extracts on Total Protein Amount in $C$. annuum var. conoides

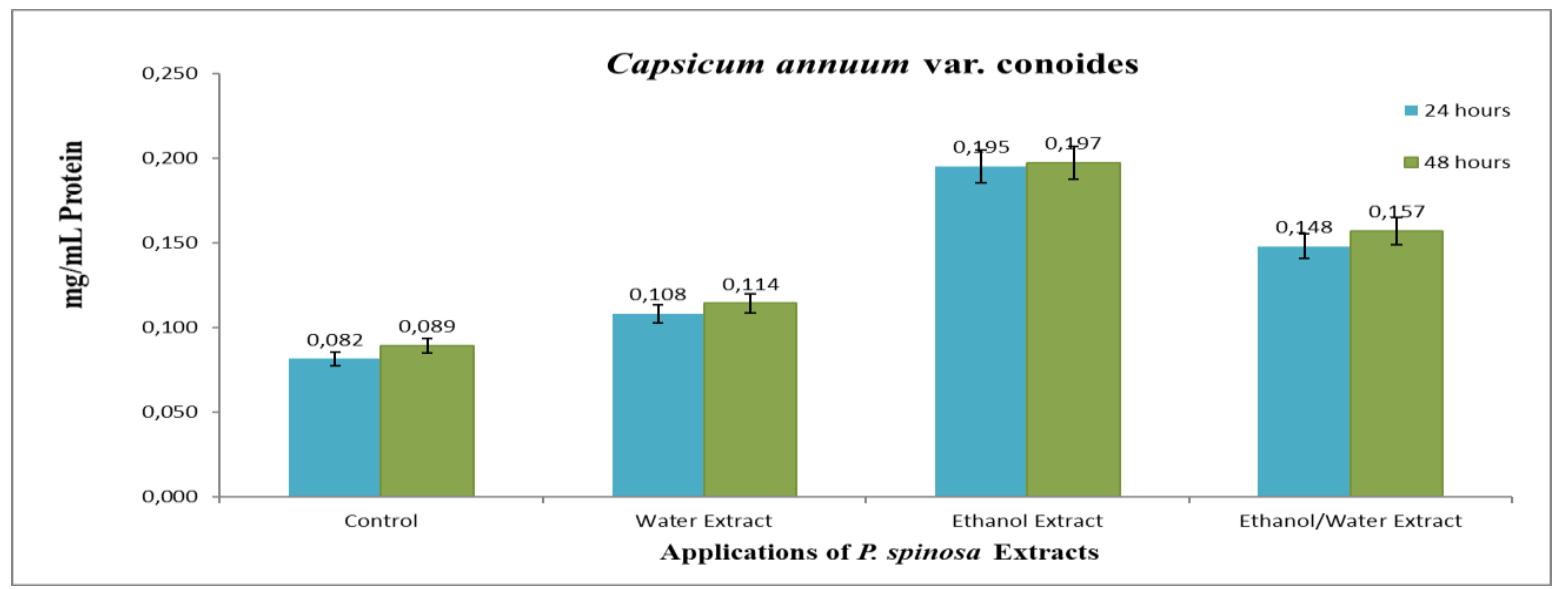

24 and 48 hours after application of ethanolic $R$. sanctus extract to conoides variety, total protein levels increasing have been found respectively as $152 \%$ and $138 \%$.

Fig. 4 Effects of $R$. sanctus Extracts on Total Protein Amount in $C$. annuum var. conoides

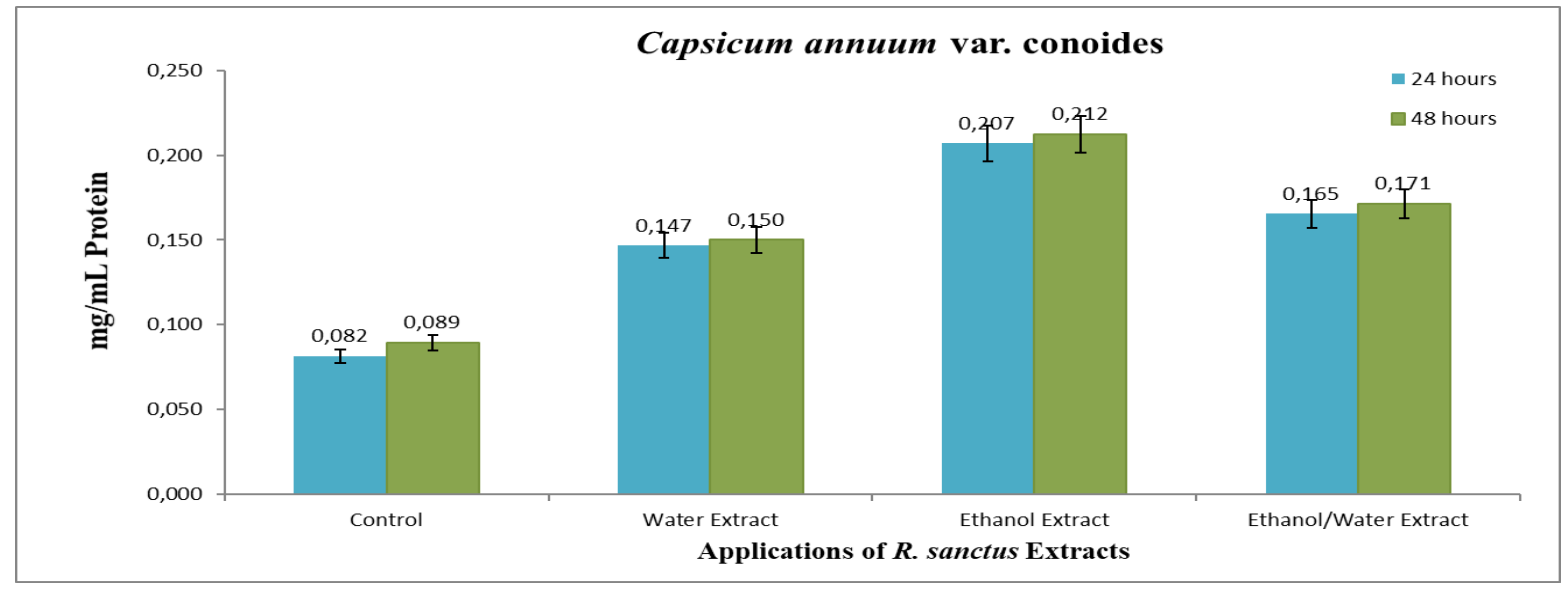

As a result, application of Rubus sanctus fruit extracts increased the total protein amount of Capsicum annuum seedlings compared to the application of Prunus spinosa fruit extract. There weren't significant difference between the varieties in terms of a total protein of the seedlings. 


\subsection{Peroxidase Results}

All extracts were found to increase peroxidase (POX) [EC 1.11.1.7] activity in pepper seedlings. The extract that increased the maximum POX activity of the pepper seedlings was ethanol extracts.

24 and 48 hours after application of ethanolic $P$. spinosa extract to grossum variety, POX activity increasing have been found respectively as $33 \%$ and $28 \%$.

Fig. 5 Effects of $P$. spinosa Extracts on POX activities in $C$. annuum var. grossum

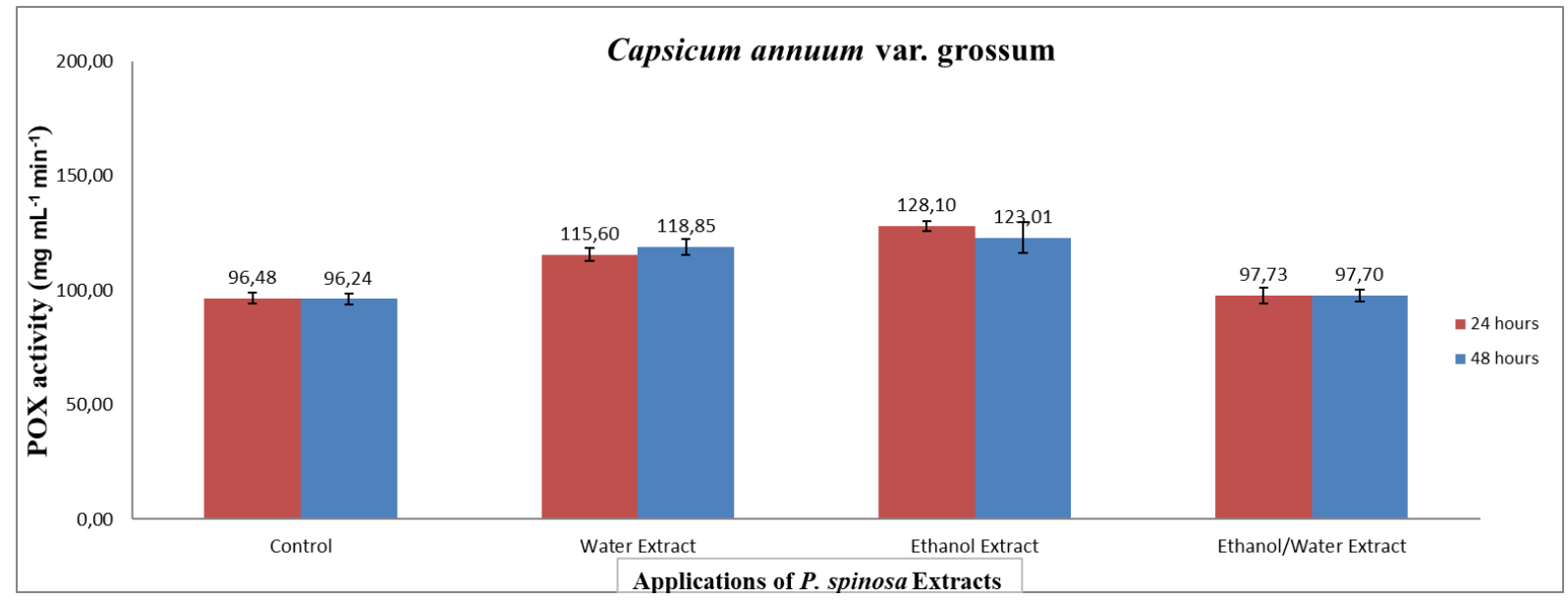

24 and 48 hours after application of ethanolic $R$. sanctus extract to grossum variety, POX activity increasing have been found respectively as $53 \%$ and $67 \%$.

Fig. 6 Effects of $R$. sanctus Extracts on POX activities in C. annuum var. grossum

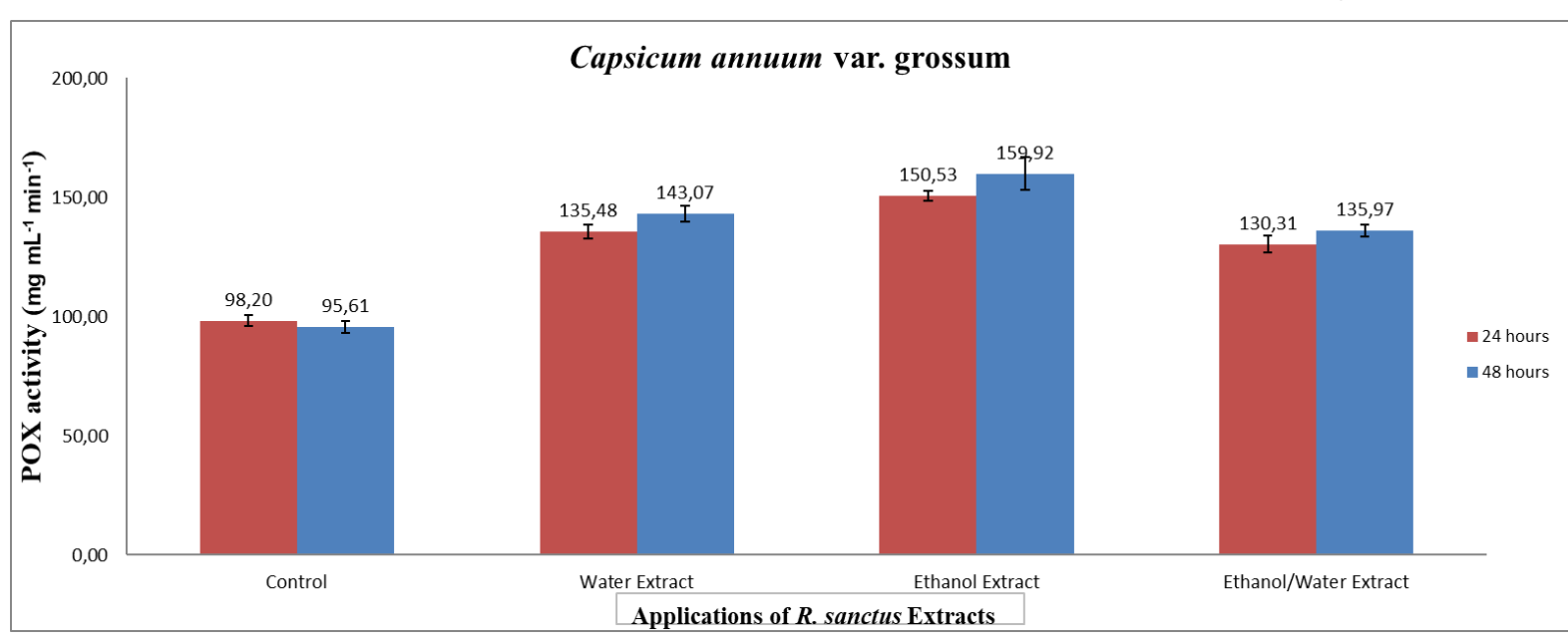

24 and 48 hours after application of ethanolic $P$. spinosa extract to conoides variety, POX activity increasing have been found respectively as $60 \%$ and $57 \%$. 
Fig. 7 Effects of $P$. spinosa Extracts on POX activities in $C$. annuum var. conoides

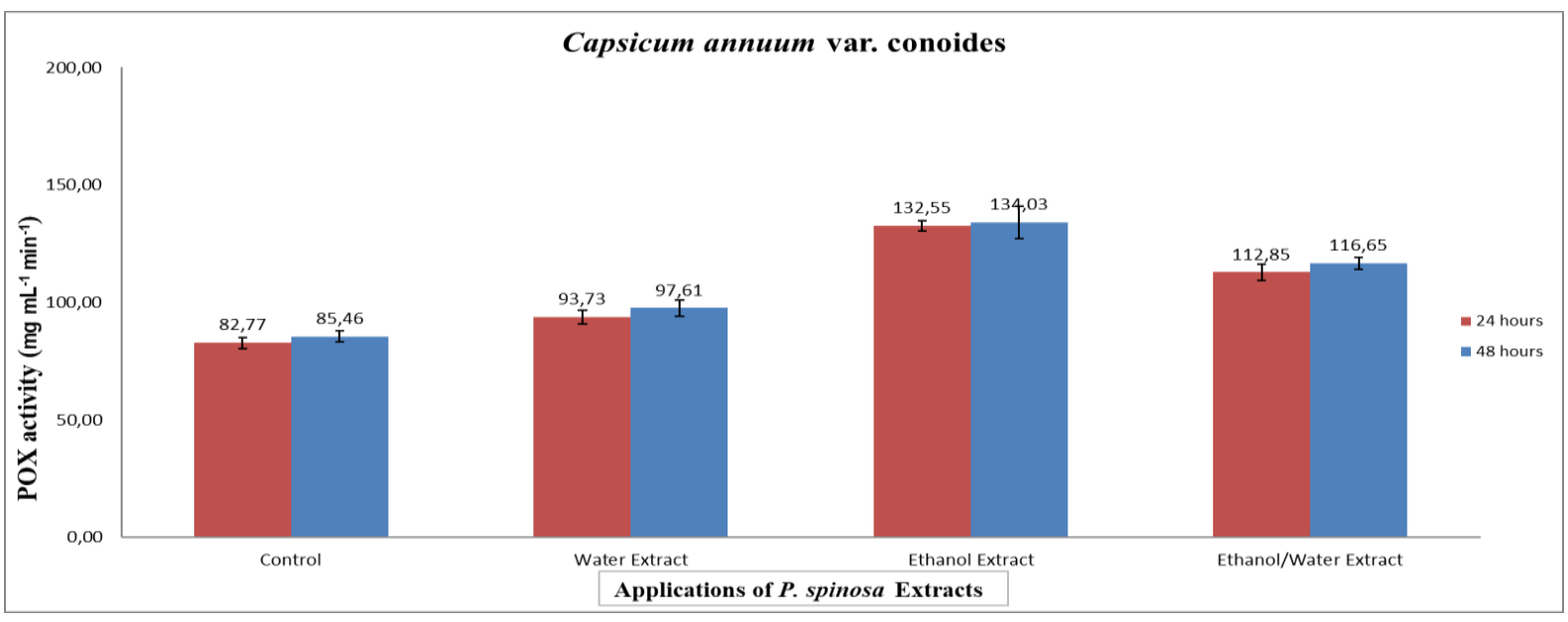

After the applications of $R$. sanctus fruit extract to the grossum and conoides varieties, POX activity changing have been found better than $P$. spinosa extract application. After the both fruit extract applications, increasing in the POX activity of conoides variety have been found better than the grossum variety. 24 and 48 hours after application of ethanolic $R$. sanctus extract to conoides variety, POX activity increasing have been found respectively as $76 \%$ and $94 \%$.

Fig. 8 Effects of $R$. sanctus extracts on POX activities in $C$. annuum var. conoides

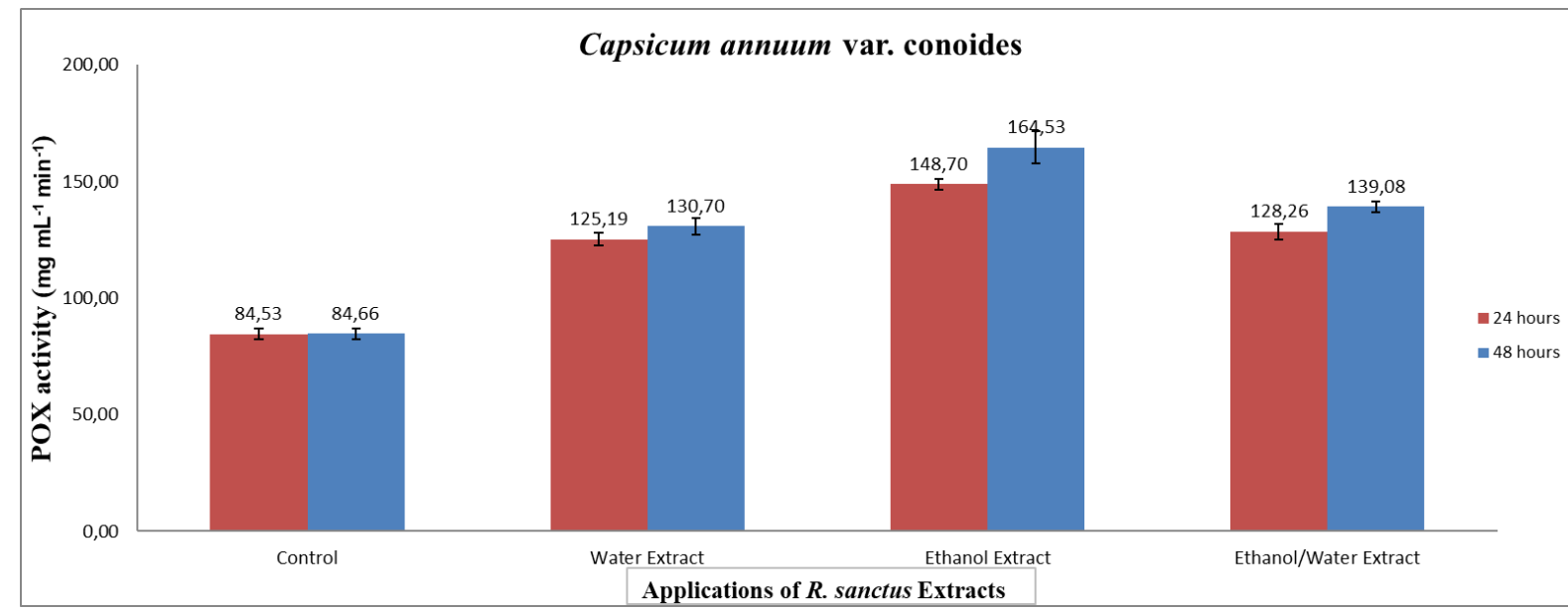

\subsection{Discussion}

In the research of Demiraslan and Ak1 (2015), in which some plant activators were applied to Capsicum annuum seedlings, plant activators were reported to increase total protein and peroxidase activity in Capsicum annuum seedlings.

In our research, $P$. spinosa and $R$. sanctus fruit extracts, like plant activators, were shown that the plant increased both total protein and POX activity at the same time.

Both Aloe vera and Echinacea angustifolia extracts showed increase in the POX activity in the application plants but the extracts showed decrease in the amounts of total protein in the application plants (Dinç,2016; Kulaksız,2016).

There are a study that was determined effect of $P$. spinos $a$ and $R$. sanctus leaf extracts on the total protein amount and POX activity in C. annuum seedlings (Y1ld1z and Ak1, 2018). When we compare this research with fruit application research, it was seen the fruit extracts, increase the total protein amount of $C$. annuum seedlings more than the leaf extracts. 


\section{CONCLUSION}

Pesticides are widely used in agricultural production, which protect plants from diseases, insects or weeds (Kannan et al., 1997). Although pesticides are developed through very strict regulation processes to function with reasonable certainty and minimal impact on human health and the environment, serious concerns have been raised about health risks resulting from occupational exposure and from residues in food and drinking water (Damalas and Eleftherohorinos, 2011). Natural plant activators are important because of the potential to reduce or no use of pesticides. Natural plant activators are important in this context. It was determined that fruit extracts which prepared from the $R$. sanctus and $P$. spinosa plants could stimulate the defense system of the pepper plant. The results in this research are consistent with the results of the previous research results that plant extracts can be used as natural plant activators. In this research, promising results have been obtained that $P$. spinosa and $R$. sanctus fruits contents could be used as plant activator developmental studies. However, more scientific research is needed to evaluate that these fruit extracts can be used as plant activators.

\section{Acknowledgments}

This research is a part of Cahit YILDIZ's Master of Science Thesis project which supported financially by Çanakkale Onsekiz Mart University Scientific Research Projects Coordination Unit by FYL-2018-2484 project code. 


\section{REFERENCES}

BAĞDAT, R.B., 2006, Tıbbi Ve Aromatik Bitkilerin Kullanım Alanları, Tıbbi Adaçayı (salvia officinalis 1.) Ve Ülkemizde Kekik Adıyla Bilinen Türlerin Yetiştirme Teknikleri, Tarla Bitkileri Merkez Araştırma Enstitüsü Dergisi, 15 (1-2), 19 - 28.

BRADFORD M.M., 1976, A Rapid and Sensitive Method for the Quantitation of Microgram Quantites of Protein Utilizing The Principle of Protein Dye Binding, Analytical Biochemistry, 72, 248-254.

DAMALAS, C.A., and ELEFTHEROHORINOS, I.G., 2011, Pesticide Exposure, Safety Issues, and Risk Assessment Indicators, International Journal of Environmental Research and Public Health, 8, 1402-1419.

DEMIRASLAN, Ö.K., and AKI, C., 2015, The effects of plant activators on total protein and peroxidase levels in in vivo and in vitro growth Capsicum annuum L., Annals of Biological Research, 6 (9), 43-47.

DİNÇ, A.G., and AKI, C., 2015, Effects of Echinacea angustifolia Hell. extracts on total protein and peroxidase changing in Solanum lycopersicum L., Annals of Biological Research, 6 (12), 25-29.

DİNÇ, A.G., 2016, Echinacea angustifolia Hell. Ekstraktının Solanum lycopersicum L. Bitkisinin Toplam Protein Miktarı ve Peroksidaz Aktivitesi Üzerine Etkileri, Thesis (MSc), Çanakkale Onsekiz Mart University.

GOUPIL, P., BENOUARET, R., CHARRIER, O., HALLE, A., RICHARD, C., EYHERAGUIBEL, B., THIERY, D., LEDOIGT, G., 2012, Grape marc extract acts as elicitor of plant defence responses, Ecotoxicology, 21, 1541-1549.

KANNAN, K., TANABE, S., GIESY, J.P., TATSUKAWA, R., 1997, Organochlorine pesticides and polychlorinated biphenyls in foodstuffs from Asian and oceanic countries, Reviews of Environmental Contamination Toxicology, 152, 1-55.

KANNER, J., and KINSELLA, J.E., 1983, Lipid Deterioration Initiated by Phagocytic Cells in Muscle Foods: $\beta$-Carotene Destruction by a Myeloperoxidase-Hydrogen PeroxideHalide System, Journal of Agricultural and Food Chemistry, 31, 370-376.

KULAKSIZ, S., 2016, Aloe vera L. Burm. F. Jelinin Capsicum annuиm L. Bitkisinde Toplam Protein Miktarı ve Peroksidaz Aktivitesi Üzerine Etkileri, Thesis (MSc), Çanakkale Onsekiz Mart University.

YILDIZ, C., and AKI, C., 2018, Prunus spinosa L. ve Rubus sanctus Schreb. Yaprak Ekstraktlarının Capsıcum annuum L. Çeşitlerinde Toplam Protein Miktarı ve Peroksidaz Aktivitesi Üzerine Etkilerinin Belirlenmesi, Journal of Awareness, 3, Special Issue, 609-616. 